\title{
The influence of architecture on real estate market value: A methodological framework
}

\author{
Valentinas Navickas \\ School of Economics and Business, \\ Kaunas University of Technology, \\ Lithuania \\ valentinas.navickas@,ktu.lt
}

\section{Tomas Skripkiūnas}

School of Economics and Business,

Kaunas University of Technology,

Lithuania

tomas.skripkiunas@,ktu.edu

\section{Justyna Tanas}

WSB University in Poznan,

Poland

justyna.tanas@wwsb.poznan.pl

\section{Maria Trojanek}

Calisia University - Kalisz,

Poland

m.trojanek@akademiakaliska.edu.pl

Abstract. The built environment takes a core position between architectural professionals, economists, geographers, and other fields. The object of this research is the mechanism of value transfers between architectural objects and their market value. Architecture is the art and science of designing space from the macro level of urban planning, urban design, and landscape architecture to the micro level of construction details and, sometimes, furniture. Architectural variables in econometric models are used to identify spatial dependency, spillovers of value, externalities, links between 'good' architecture and market value, heritage aspects, contributions to sustainable development, and architecture as public good. While many studies have focused on the determinants of the real estate market value, the aim of this research is to capture the areas of influence of architectural variables on the market value of a property. To structure that influence, we analyzed the types of value a built environment 
can generate and the determinants of real estate market value. A mechanism of value transfers between architecture and the real estate market value is presented in a proposed framework. The implications of the framework and future research are discussed.

Keywords: real estate market value, price determinants, architectural variables, externalities, methodology

JEL Classification: R31, R32, D46

\section{INTRODUCTION}

The research on built environments is rather fragmented between architectural professionals, economists, geographers, and other fields. However, in the context of social, cultural, economic, and environmental values, the built environment occupies a core position. Architecture is the basic element that co-creates the human environment (inside the building as well as in the built landscape). It is therefore seen through the prism of technology, engineering, most often construction (a narrow approach), culture, and art and the processes of shaping space (a wider approach). In the past, the role of the architect was to design functional and beautiful buildings. Currently, there is a need to consider other requirements, such as the friendliness and accessibility of the environment, rationality and space saving, biodiversity, and saving natural resources, especially energy and water. These include studies on spatial dependency and architectural design or style and their impact on the real estate market value. While many studies have focused on determinants of the real estate market value, the aim of this research is to capture the areas of influence of architectural variables on the market value of the property. There is a critical emphasis in this study on the monetary dimension of the real estate valuation, which omits the nonmarket properties of the real estate.

A scientific problem that is raised is that architecture's influence on the real estate market value is not structured, and most research is done from determinants of the market value perspective, but this lacks a systemic overview of the transfers of value between the built environment, its market value and the public policy dimensions. The scope of this research is to fill the research gap between studies about the economic outcomes a built environment generates and studies about the determinants of the real estate market value. The scientific novelty of this research is an attempt to connect these two areas of research in one theoretical framework that may identify possible ways to improve the understanding of links between the architecture of a built environment and its market value. The basis for consideration is the assumption that the economic value of the property is influenced by the decisions made by architects and their teams, and vice versa, the economic value of the property influences the decisions made in the process of architectural and urban planning design. The primary object of the research is the mechanism of value transfers between architectural objects and their market value. Further objectives are to systematize the architectural variables in real estate economics, establish interrelationships between architecture and real estate economics, structure the concept of value of real estate looking at what built environment generates, and investigate the determinants of the real estate market value.

In the theoretical part of the study, we attempted to systematize the conducted research on architectural variables and the market value of the real estate. The analysis showed that the studies have a fragmentary character, concern selected factors describing the architecture and do not consider the mutual relations and connections. The further part of theoretical arguments concerns the interpretation of the market value of the real estate. The concept of economic value adopted in the study treats the real estate as an element of the environment, taking into account the mutual relations and interaction. The economic value of the 
property is determined not only by its monetary dimension. These issues are considered in the methodical part of the article, which identifies the areas of architectural influence on the market value of the property and presents the framework for future research.

This article utilizes existing knowledge on the researched topic introducing a systemic theoretical analysis, practical construction method, and visualization of the theoretical perspective. The interpretativeconstructive methodological approach was chosen, which enabled us to reveal an estimation of the researched phenomena and the structure of it.

\section{THEORETICAL BACKGROUND}

\subsection{Architectural variables in economics}

Architecture should shape a human friendly space combining form and function. Space is a limited good with strictly defined size, features, and patterns, without the possibility of multiplication, which in turn creates competition and conflicts in the process of space management. Therefore, it is necessary to search for an appropriate and optimal way to use a space to determine the best possible function for a given area generating 'highest value' and 'best use'. Although architecture can be seen in many ways, the definition of architecture as art and knowledge of space is used and extended in this article. Architecture is not a physical object but rather space that is functional and represents the 'best use'.

The notion of architectural variables in this study refers to quantitative and qualitative measures of a built environment that can be taken to reflect that 'best use'. Particular measures are neither positive nor negative in nature. For example, building intensity might be considered good or bad depending on the location and use, as well as social, political, and cultural background. Being location specific, architectural variables are, thus, hard to define; however, it is the essence of architecture to generate the 'highest value' for a given area. To give an example, if we have limited space as mentioned before and limited resources to build a housing block, would it be 'best use' to allocate all resources to build housing units or would it be better off with some left for a park or communal space? Similarly, is it worth adding a nonstructural layer for facade complexity rather than saving on investment or building more housing units instead? The idea of these variables becomes even more complicated when we consider this housing block as an externality or public good to the inhabitants and visitors of a district or a whole city. The hypothesis is raised that architectural variables can influence individual economic and public policy outcomes.

In addition to this, the field of architecture may be referred to in the following senses:

1. The widely speaking sense (from urban planning and urban design to building and interior design);

2. The narrowly speaking sense (mainly buildings and style).

The focus here is on the scope of the design tasks an architect may carry out. A widely speaking definition often includes the design of the total built environment from the macro level of urban planning, urban design, and landscape architecture to the micro level of construction details and, sometimes, furniture. The object of architectural design is everything that shapes the space around us whether inside or outside, be it a building or other structure. As opposed to this, narrowly speaking, architecture is just buildings in space. For example, a new bridge is proposed. This would reduce transportation costs in the city. This would alter the attractiveness of some areas for shopping and services, increase the potential for advertising and improve the investment background. This would have an impact on the housing characteristics in that area, therefore, changing the variables in hedonic house price models. The way we look here at architecture is broadly speaking and defined by space because it includes all our surroundings, be it a system of streets and bridges or districts and buildings, including the outside and inside. 
Spatial dependency, spillovers of value, externalities. The problems of spatial effects have been ignored in real estate analysis to an extent. However, there is research to identify house price determinants regarding their location and surroundings Cellmer \& Trojanek, 2019; R. Trojanek, 2016; R. Trojanek et al., 2018; R. Trojanek \& Huderek-Glapska, 2018; Radosław Trojanek et al., 2019). This confirms that real estate data is highly spatially dependent. In recent decades, spatial econometrics was used to incorporate neighborhood dynamics and spillovers of house prices into the traditional hedonic model (Anselin, 1988) (Can, 1990) (Le Sage, 1998, 2009) (Wilhelmsson, 2002, 2004). Other spatial econometric approaches, like the distance to urban focal points in the city, have been tested and their influence on prices confirmed (Gat, 1998; Gong et al., 2016).

There is research on how to better incorporate those spatial econometric models in recent studies comparing different spatial econometric methods (Stamou et al., 2017). Spillovers of value in micro scale environments have also been studied. Research showed that houses designed by Frank Lloyd Wright (a famous American architect) have a positive effect on the prices of houses nearby (Ahlfeldt and Mastro, 2012). A price impact of attractive neighboring buildings was also captured with a computer vision technique (Glaeser et al., 2018). These interventions suggest that buildings in urban environments are affected by the appearance of the buildings that surround them and their position related to the urban structure of the city.

Urban and architectural design quality variables. Many studies attempted to add qualitative variables or expert ratings to hedonic regression models. One of the earliest studies by Hough and Kratz (1983) assessed the influence of architecture on office rent prices in downtown Chicago using regression analysis. New commercial buildings that won architectural awards had a $22 \%$ rent premium; however, landmark status buildings, as measure of good architecture for older buildings, did not benefit and suffered from a price discount due to difficulties in renovations and government permissions.

Vandell and Lane (1989) evaluated office buildings in Boston and Cambridge to understand the effect of good architecture on their construction costs, rent levels, and vacancy rates. They found that the better the design quality of office buildings, the higher the rent; however, the relationship between vacancy rates and the design was weak. They surveyed architects and used disaggregation analysis to measure the quality of architecture. They also acknowledged that good design usually costs more but is not necessarily the case. This was followed by Asabere et al. (1989) finding a price premium for certain architectural styles in Newburyport, Massachusetts. Fuerst et al. (2011) proved that offices designed by famous architects had higher rent levels than those whose designer was less famous.

The attractiveness of historic areas was estimated, including style and building type variables as control variables, in a model by Coulson and Lahr, 2005. Different aspects of design quality in apartment units in the Belfast City Centre were evaluated by applying and extending the hedonic model to include building and urban level quality variables (Nase et al., 2016). Research was performed on measuring the price effect of the neo-traditional architectural style of buildings, which does affect the willingness to pay (Buitelaar and Schilder, 2017). All these studies linked architecture to the value of buildings, and they mostly found a positive relation between good design and the real estate market value.

Heritage aspects. Architecture is perceived by people through our mind and memory; therefore, our collective memory gives a meaning to places, altering the valuation of the real estate. There are various hedonic price analyses that look at historic buildings. A price premium was found in cases that involved listed buildings themselves, neighboring buildings to listed buildings and cultural historic site areas (Lazrak et al., 2014), and historic districts in New York (Been et al., 2014). In a recent study by Rudokas et al. (2019), landmark buildings were more expensive to maintain, therefore, resulting in lower rent prices. However, they act as positive externalities for neighboring buildings.

Research was conducted to analyze heritage aspects, like the status and features of a building or historic built environment as well as the influence on real estate prices using the hedonic price method. While no 
significant influence on price was found regarding the heritage status of a building, the heritage in general played an important role in the price of new buildings that were being developed in the surrounding area of heritage buildings or environment. Authors noticed spillovers of the value of heritage buildings that resulted in a significant increase in neighborhood house prices (Rudokas et al., 2019). The influence of the heritage aspects of architecture to the real estate market value were found in most cases, in particular when considering new buildings adjacent to listed buildings and historic site areas.

Sustainability. The need to evaluate the effect of architecture on the value of sustainable houses is addressed. Architectural design integrates a great variety of decisions in a building project, including orientation, window placements, space configuration, and the choice of finishing materials (Fadaei, 2015). Good design can attract clients for sustainable houses, therefore, resulting in price premiums for investors of sustainable houses. If people know that they can save $25 \%$ on energy bills by buying a correctly solar orientated house, they will become motivated to select that house over the same house with the wrong orientation, contributing to today's environmental discourse (Rashkin, 2010).

The evidence of the built environment quality on environmental outcomes was found in various other studies as well. Urban form has an impact on the energy consumption (Ewing and Rong, 2008; Ratti et al., 2005; Chen et al., 2011; Lee and Lee, 2014), mobility, and services in the city (Zhou et al., 2013; Nakamura and Hayashi, 2013). Urban design and landscape design have an impact on the microclimate (Bowler et al., 2010; Ko and Radke, 2014; Jamei et al., 2016), air pollution, and noise (Honold et al., 2012). The design of a built environment is strongly related to the material use and embodied energy. Generally, a great deal of architectural solutions can contribute to achieve sustainability goals in real estate economics.

Architecture as nonmarket or public good. Referring to architecture as a public good in a city, the value to its inhabitants and tourism may be captured. Scerri et al. (2019) noticed that special local characteristics of place are captured and enhanced by architecture, and tourists are attracted to consume its unique design qualities. As with other nonmarket goods, tourist expenditure is not an architecture's explicit objective; however, architects, city municipalities, and cultural organizations are aware that architecture is a visitor attraction on its own. This makes architecture an externality or public good that contributes significantly to economic activity.

In their study, Scerri et al. (2019) attempted to calculate the overall economic impact of a building annually. These include examples, such as the Guggenheim museum Bilbao, the Sydney opera house and the Gehry-designed Dr Chau Chak Wing building, the latter being worth somewhere between AUD 48.8 and AUD 97.6 million to the economy annually (Scerri et al., 2019). The consumption of space by tourists and their mobility highly influences economic activity in cities. The pattern of consumption is highly influenced by the positioning of architecture landmarks, public space, and urban design structure (Aranburu et al., 2016). There is an implicit market for environmental goods in the city. We do not explicitly purchase nonmarket goods; however, we do purchase other goods for which the demands are related to nonmarket goods. For example, environmental quality can influence where to live, work, and relax (Champ et al., 2017). Regarding architecture, we do not explicitly purchase architectural quality, or widely speaking, architecture. Here and further, architecture, or some part of it, may be perceived as a nonmarket good. The real estate market links to nonmarket goods make it possible to infer values for the demand of architecture as a nonmarket good revealed through house purchases.

\subsection{Interrelationships between architecture and the real estate economics}

In the search for the mechanism of the influence of architecture on real estate economics, objects of the built environment become a mediator between architecture and economics. The interrelationships between architecture and the built environment, presented in figure 1, are as follows: 
1. Architecture - attribute of the built environment that is capital or a product (it is tangible, shapes physical structures and is a part of market goods and relates to hedonic price models).

2. Architecture - art, design, image, style, vision or orientation that influences human economic behavior (it is intangible and abstract and, thus, difficult to incorporate into market evaluation, partially acts as a nonmarket good, and relates to studies about quality variables, nonmarket, and public goods).

3. Architecture - a significant part of ecosystem we live in (relates to studies about sustainability).

The first interrelationship comprises the narrowly speaking sense of architecture. This shows that architecture has an influence on this large market. The housing market is larger than the value of the entire stock market in most countries, particularly in the Baltic States (Jadevicius, 2016). In the Baltic States, the amount of outstanding housing loans to households was EUR 19.0 billion in 2018 (Hypostat, 2019), and the market capitalization of the listed companies was EUR 6.7 billion (Nasdaq Baltic, 2019). Architectural assets hold tangible and intangible value. While the first interrelationship is about shaping tangible assets, the second interrelationship is about the intangible value of buildings, which can be described in various forms including aesthetic and cultural values (Scerri et al., 2019), the sense of place, and the historical and social meaning (Hayllar et al., 2008).

Regarding the third interrelationship, architecture is a significant part of ecosystem we live in and its sustainability. Architecture may not be replaced by other products or services even in the long term. Cities, public spaces, and shelters are the main pillars people relate to. The concept of sustainability should not be based only on market models, especially in short term, as the influence of the given nature of our universe is dominant in architectural design. The way the space is managed has a significant impact on the functioning of the economy and on the value of resources (the land, natural and cultural landscape, and environment).

Subordination of investment procedures to the principles of sustainable development is a source of benefits for the economy (reduction of losses resulting from wrong administrative decisions and improvement of investment processes), social benefits (reduction of social conflicts and a higher quality of life), and benefits for the natural and cultural environment (reduction of negative consequences for the environment, better value protection in both spheres of heritage). To summarize, the first interrelationship shows that architecture deals with stock that has quantitative significance in microeconomics and macroeconomics. The latter two interrelationships show a broader influence on society and economic behavior. 


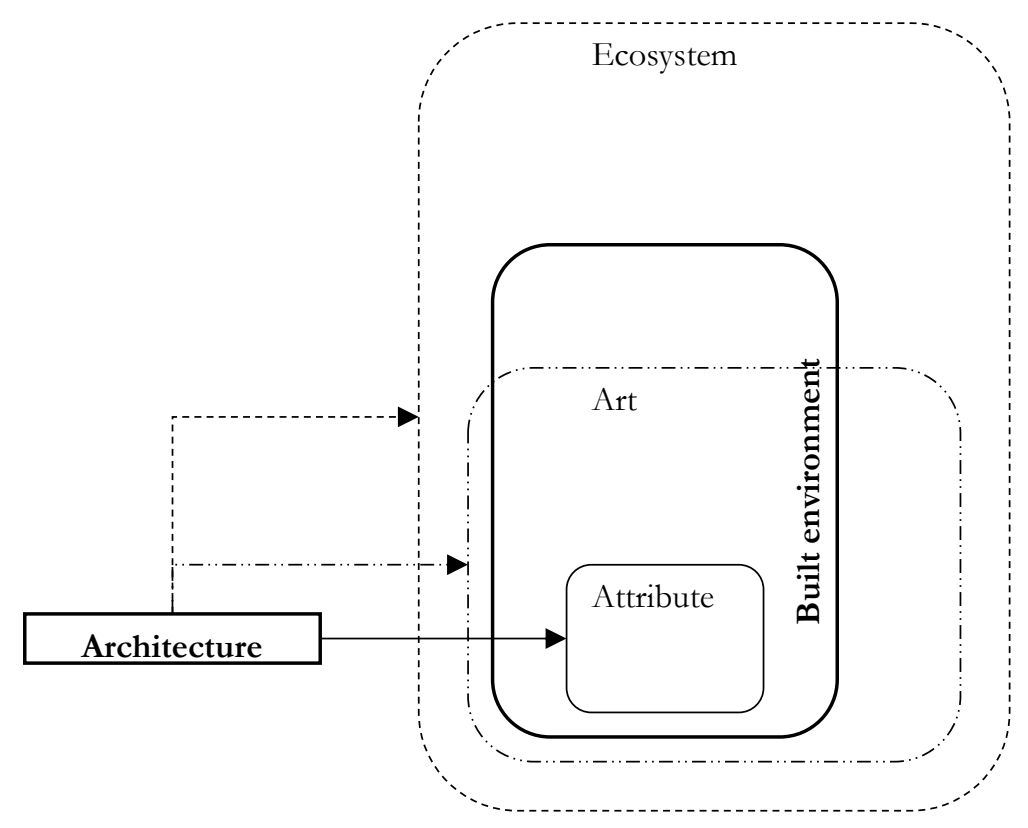

Figure 1. Interrelationships between architecture and built environments

Source: own evaluation.

Through these interrelationships, the impact of architecture on a built environment may be:

1. Quantitative. Architectural design has an influence on the effectiveness of the geometry of a building, the heating and cooling capacity, the natural lighting, and the use of land and materials. As described before in this article, the orientation of a building, amount of glazing, thermal capacity, and types of materials have impacts on the overall performance of a building (Fadaei, 2015).

2. Qualitative. Architecture is an influential generator of value. The value transferred is highly intangible and, therefore, impossible to quantify. However, later in the process, health, social, economic, and environmental outcomes can be quantified.

We expect functional technical decisions in tandem with aesthetics from architecture. There should be a balance between quantitative and qualitative measures in architecture, as going for the maximum rate in quantitative assessments would render all buildings the same. Although there is evidence that various quantitative and qualitative variables of architecture have influence on real estate market values, the influence of architecture, in a broad sense, on real estate economics is not structured. Architectural variables in econometric models are taken as immutable and fixed; therefore, little research has been done to simulate different scenarios of architectural design and forecast possible impacts.

When talking about the influence on real estate economics, the influence must be quantitative and expressed through the market value or various statistics of location and macroeconomic variables. The influence of the built environment on real estate economics is quantified and highly influenced by the real estate valuation methods used; however, the accuracy and mechanism of those methods are not in the scope of this study.

Architectural variables should not be assumed to be exogenous. There are many omitted variables that influence architecture and the real estate market. The market value of real estate tends to move together with other asset prices. Real estate, especially housing, is consumption and investment at the same time, 
thus, becoming a consumer choice and speculative asset. There may be larger players, such as the credit supply, GDP, or interest rates, that have an overriding influence on housing consumption. There may also be certain trends or desires in society resulting in irrational human behavior that is hard to explain in econometric models. Therefore, the mechanism of architecture influence on the real estate market value as described in this study should be considered at a fixed time as capable of shifting over time.

\subsection{The concept of value of the real estate}

A distinction between two concepts of value is made by philosophers:

1. Intrinsic value- "that which is desirable or worthy of esteem for its own sake; thing or quality having intrinsic worth" (Webster's New World Dictionary, Third College edition) "if it is valuable in and for itself - if its value is not derived from its utility, but is independent of any use or function it may have in relation to something or someone else. [...] an intrinsically valuable entity is said to be an 'end-in-itself', not just a 'means' to another's ends" (Callicott, 1989).

2. Instrumental value - the value, according to this concept, lies in its contribution to some other goal, a 'means' to some other end or purpose (Costanza \& Folke, 1997).

The market value of the property reflects a mix of these two concepts. The usefulness of the property is captured by its instrumental value; however, architecture, as the art and science of designing a space, can hold intrinsic value that may affect the willingness to pay. It is difficult to draw a separation line here, but, for example, a traditional shape, particular style, or material of a house may have more intrinsic value compared to the plan arrangement or number of floors, although some properties considered intrinsic could have halfway instrumental explanation.

In the context of social, cultural, economic, and environmental values, the built environment occupies a core position that shapes our behavior. Therefore, the concept of the value of real estate can be approached from two different perspectives:

1. The value the built environment generates;

2. The determinants of market value as a measure of impact on the real estate economics.

These two approaches are presented in the following sections of this article.

The value the built environment generates. This was revealed by a systematic study by Carmona (2019). It was backed up by 271 research studies that were included in the review focusing on the added value of the quality of a space. The full range of the public policy dimensions covered by Carmona (2019) is presented in Table 1. 
Public policy dimensions covered.

\begin{tabular}{|l|l|}
\hline & Public policy dimensions \\
\hline Health & A1. Greenness and physical health \\
& A2. Greenness and psychological well-being \\
& A3. Place quality and mental health \\
& A4. Walkability, active travel and related health \\
& A5. Place quality and physical health \\
\hline Society & B1. Street layout and crime \\
& B2. Environmental design and crime \\
& B3. Street design and safety from collisions \\
& B4. Place quality and livability \\
& B5. Urban vitality \\
& B6. Inclusivity and social capital \\
& B7. Enabling environments \\
& B8. Place quality, play and learning \\
\hline Economy & C1. Property values and green space \\
& C2. Residential property values and urban design \\
& C3. Commercial property values and urban design \\
& C4. Streets, public realm and economic value \\
& C5. Economic development and regeneration \\
& C6. Public spending (and savings) \\
\hline Environment & D1. Urban form, density and energy use \\
& D2. Transport, technology and carbon reduction \\
& D3. Thermal comfort, cooling and pollution \\
& D4. Ecology and resilience \\
\hline
\end{tabular}

Source: Carmona (2019).

The collective evidence on place value is a collection of health, social, economic, and environmental outcomes. The way places are designed plays an important role in delivering better physical health, mental health, better fitness, greater daily comfort, and enhanced quality of life. The social evidence corresponds to fewer accidents, social integration, lower rates of crime, better educational outcomes, enhanced street level vitality and sociability, stronger civic pride, and greater inclusiveness. Economic outcomes consist of property uplift and reduced vacancy, viable investments and extended regeneration benefits, reduced public expenditure, higher local tax takes, lower costs of living, and higher productivity.

The environmental benefits from place value include reduced energy use and associated carbon emissions, adaptive reuse, a viable local exchange network, reduced heat stress and enhanced thermal comfort, reduced waste and pollution, greater resilience, and ecological diversity (Carmona, 2019). Some economic outcomes are quantitative and refer to the market value instantaneously to see the impact on the real estate economics. While the health, social, environmental, and some of other economic outcomes are beneficial to the microeconomic and macroeconomic environment overall, their impact on real estate economics is collateral through micro and macro variables as presented in the following sections of this article.

Generation of value in exchange. A problem of differentiating types of value can be discussed further. In an economic context, value is usually interpreted as a monetary amount for an exchange between a willing buyer and seller in an open market. However, two main types of value can be defined:

1. Value in exchange is the quantity of other commodities (normally cash) that a commodity can be swapped for (Carmona et al., 2001). This is what is generally called market value and is often related to the concept of price (Nase et al., 2015). 
2. Value in use is often associated with the concept of worth or the pleasure a commodity generates for its user. It is important to say that worth is not the same as price as there are various variables in the real estate market that are not perfect (inefficient). The valuation of real estate also differs widely at the international level (Nase et al., 2015).

The International Valuation Standards Council (IVSC) and Royal Institution of Chartered Surveyors (RICS) define market value as:

"Market Value is the estimated amount for which an asset or liability should exchange on the valuation date between a willing buyer and a willing seller in an arm's length transaction, after proper marketing and where the parties had each acted knowledgeably, prudently and without compulsion" (RICS, 2019).

However, this definition can be criticized for being too money-centered and with little consideration of other (physical and social) dimensions (Nase et al., 2015). Therefore, a wider conception of value, including value in use and welfare, was applied in this study. Six different types of value of built environment were identified by Macmillan (2006):

1. Exchange value. Objects of built environments are commodities to be traded. The market price is the price people are willing to pay for it.

2. Use value. The contribution of a built environment to organizational outcomes, such as productivity, profitability, competitiveness, and repeat business.

3. Image value. The contribution of a built environment to corporate identity, prestige, vision, and reputation. Creating organizational values of openness, design excellence, and innovation. Architecture working together with people to become part of a brand image.

4. Social value. Creating opportunities for positive social interaction, enhancing social identity, and improving safety and security as well as preventing vandalism and crime.

5. Environmental value. Contribution to sustainability of a built environment by using the principles of adaptability and flexibility, robustness, and low maintenance. The application of a whole-life cost approach.

6. Cultural value. Intangible phenomena, like context, sense of place, symbolism, inspiration, and aesthetics, are considered.

The various types of value described above translate to the first value in exchange. "This translation process is based on interdependent economic factors that create value, namely utility, scarcity, desire and effective purchasing power" (AI, 1996). "Utility is the ability of a good to satisfy needs. Scarcity is the supply of an item relative to the demand for it. If demand is constant the scarcity of a commodity makes it more valuable. In the case here, reduced quantities of a quality (urban design) product due to initial investment costs reflect its price in the market. Because it is inefficiently priced, urban design (as a public good product) is undersupplied by property development and house building industry. Desire is a purchaser's wish for a commodity to satisfy needs beyond the essential required to support life. This is considered in direct relation to quality as the willingness to pay a higher price for higher utility. Finally, effective purchasing power is the ability of purchasers to participate in the market" (Nase et al., 2015).

This justifies the definition by Royal Institution of Chartered Surveyors, which states that the market considers all types of value when defining an exchange value, market value, or price. This is based on utility theory as all types of value together maximizes the user utility (Nase et al., 2015). It is difficult to confirm, however, that none of the value is lost during that translation; therefore, the market value of the real estate may not reflect the whole set of values described. 


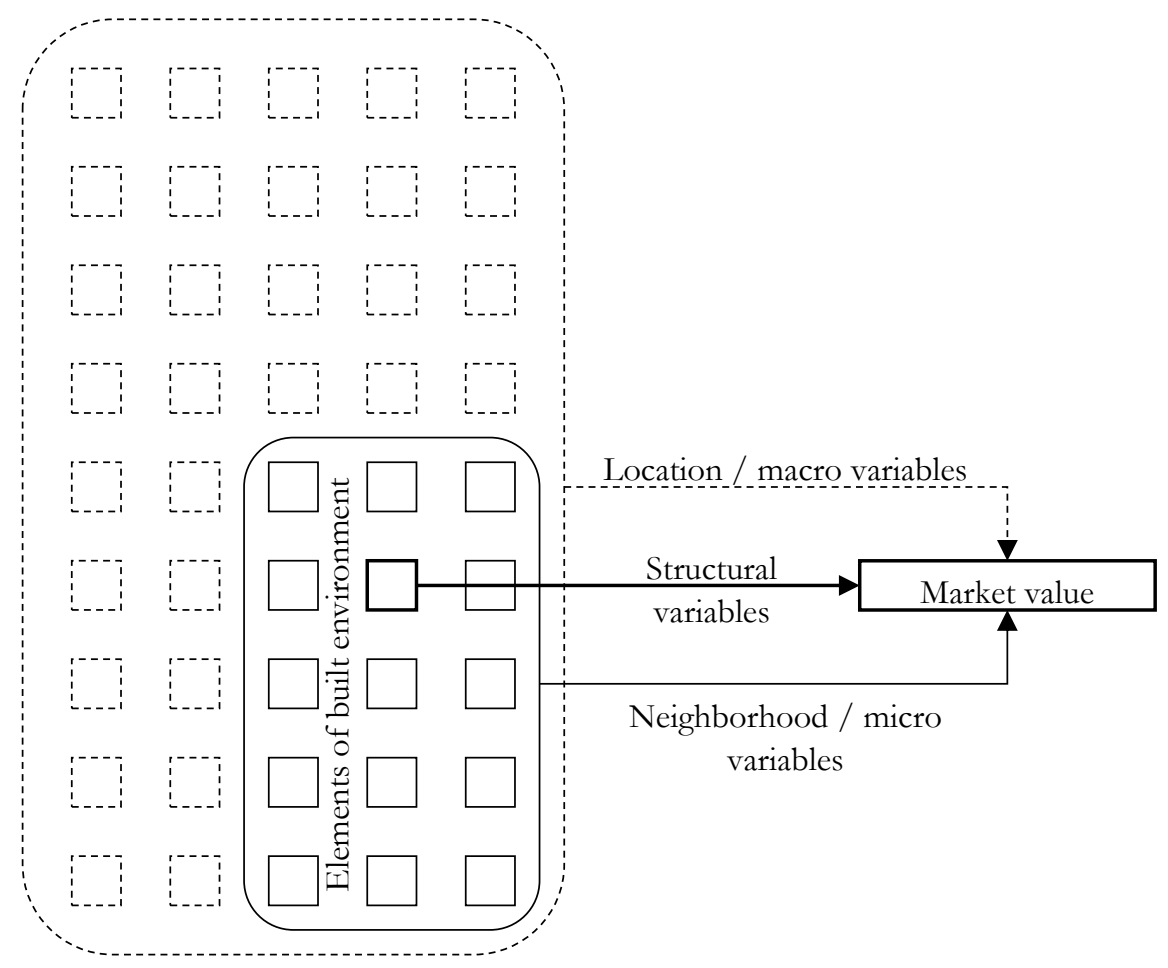

Figure 2. The structure of structural, location, and neighborhood variables Source: own evaluation.

Determinants of market value. Looking from perspective of the real estate market value, hedonic theory is based on the idea that the price of any house represents the price for a bundle of goods. Those goods, according to Dubin (1988) can be grouped into three main categories:

1. Location variables - characteristics that describe the geographical location of the object or its location relative to other objects.

2. Structural variables — attributes of the house itself (size, rooms, age, etc.).

3. Neighborhood variables-characteristics that describe the socio-economic and physical neighborhood properties (pollution, noise, crime etc.) (Can, 1992).

The location and neighborhood variables that influence a houses' market value are an outcome of the structure of the same houses and are, thus, not entirely exogenous. This is based on the theory of structuralism, which states that the structure of elements may acquire new values compared to the sum of the values of the individual elements. Those new values acquired are location and neighborhood variables as presented in Figure 2.

\section{METHODOLOGY AND RESEARCH FINDINGS}

The structure of the determinants of the real estate market value is presented in Figure 3. The determinants of the real estate market value are constructed in three main categories. The base market value, determined by structural variables, is modified by micro modifiers, determined by neighborhood variables, and macro modifiers, determined by location variables. 


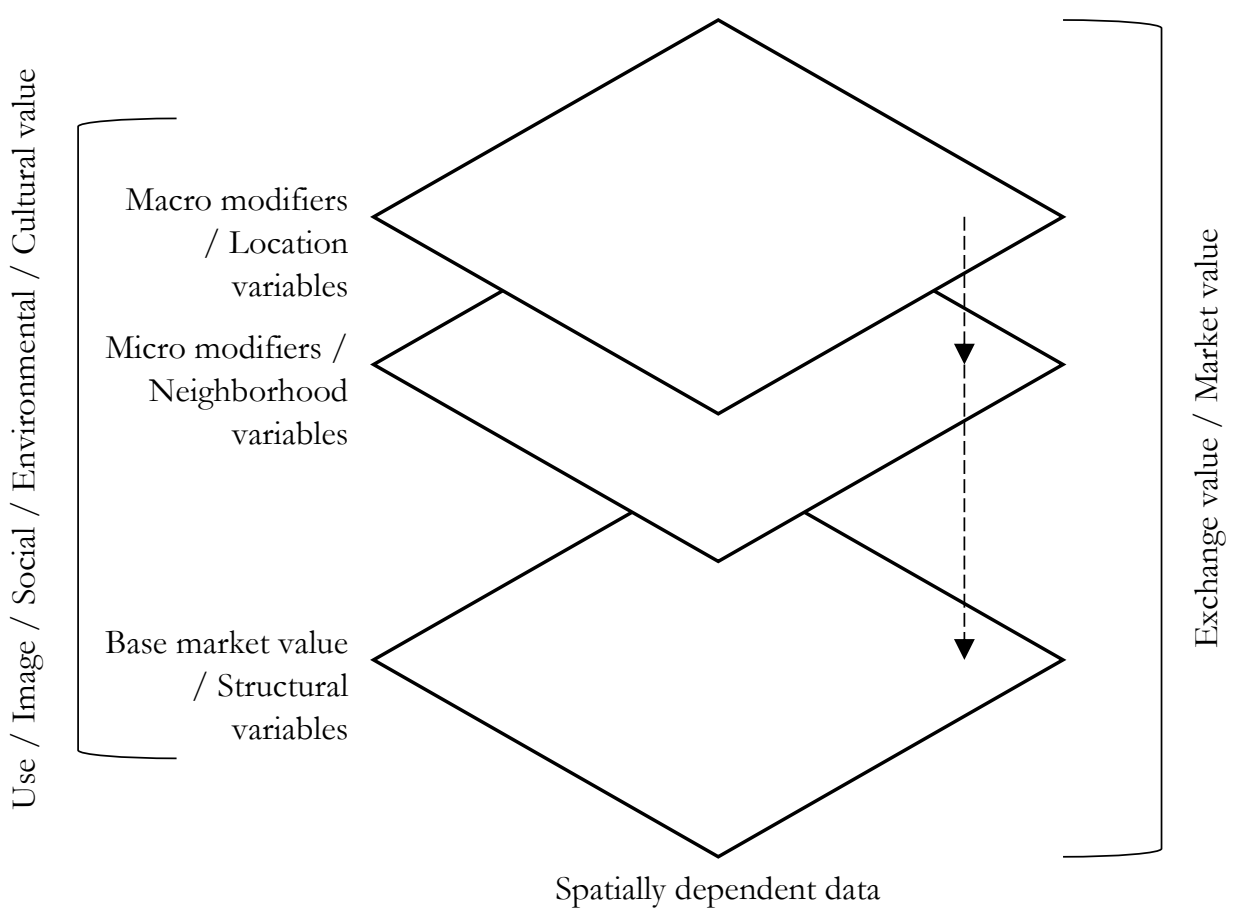

Figure 3. Determinants of the market value

Source: own evaluation.

The mechanism of value transfers is presented in Figure 4. The interrelationships between architecture and the built environment are described in Figure 1 earlier in this article. Two main directions-'value in use' and 'value in exchange' - can be taken from the built environment perspective. 'Value in use' is divided into five types of value that a built environment can generate. Although, 'value in use' and 'use value' may be inappropriate syntax here to use together, 'value in use' was chosen to refer to research done by Nase et al. (2015). There is also a distinction between market and nonmarket goods in Figure 4. Around the concept of 'market value', there is area defined by 'market' that also takes some part of the other 'values in use'. The majority of social, environmental, and cultural values fall into the area defined by 'nonmarket'. However, those values are later transferred to 'market value' through modifiers. The idea of modifiers is also described in Figure 3 earlier in this article.

The link between the 'built environment' and 'market value', as an equivalent in money, works both ways, as elements of built environments can be bought or sold. On the other side, the determination process of 'market value' goes through a series of values a built environment can generate, relying on the idea of the translation of various types of value to 'value in exchange' or 'market value'. 


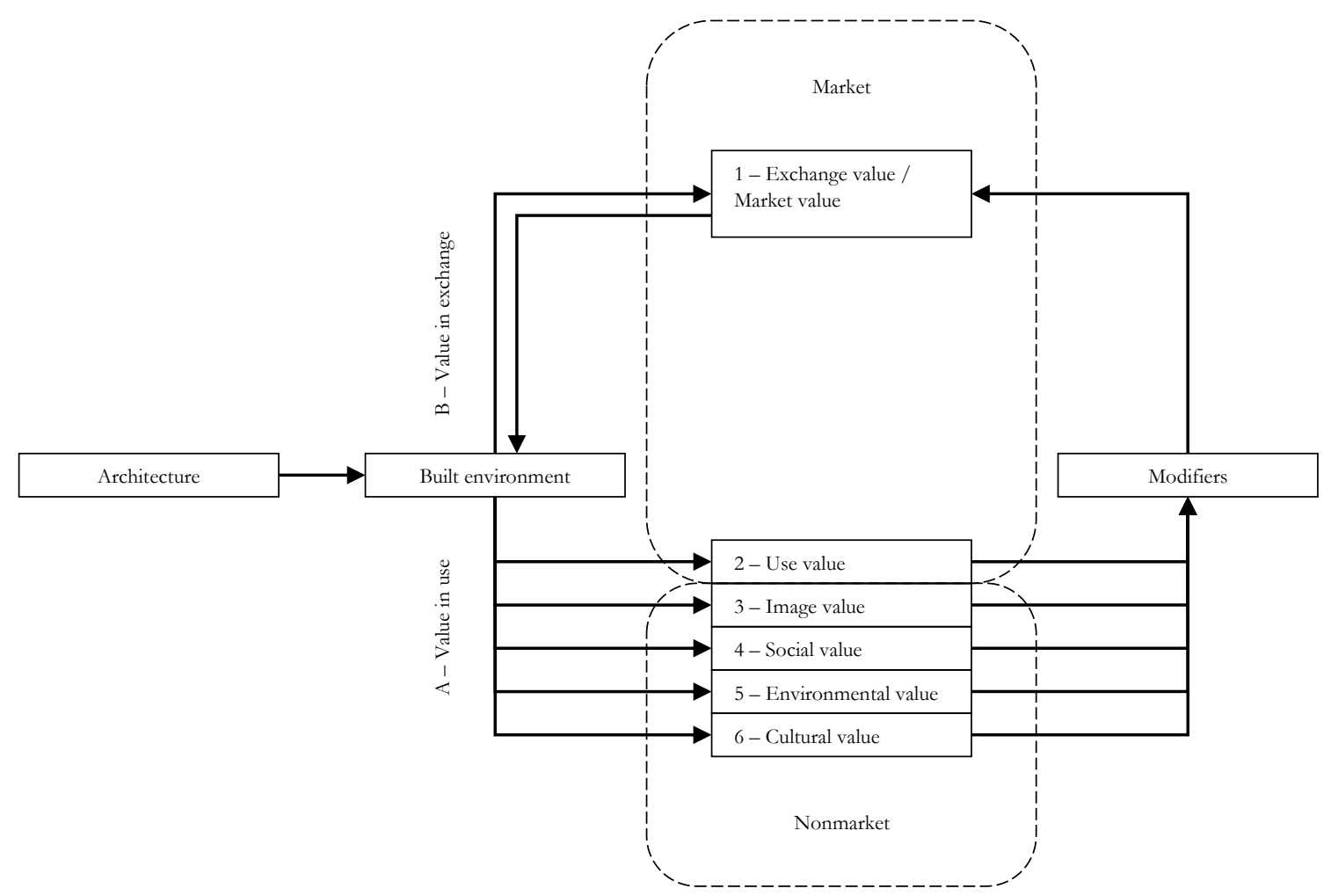

Figure 4. Transfers of value-the framework

Source: own evaluation.

\section{CONCLUSIONS}

The influence of the built environment on real estate economics may be far bigger than market value; however, it is distributed widely between all public policy dimensions. Part of the value stays in the nonmarket area, while other parts are translated to market value. Architecture plays an important role in shaping a built environment, creating influences on our economic behavior and becoming an influential generator.

The framework was constructed to fill the research gap between studies about the economic outcomes a built environment generates and studies about the determinants of the real estate market value. Value transfers can cross various areas, either market or nonmarket. The paradox here is that even while talking about the real estate 'market value', determinants of that value are highly dependent on nonmarket goods. The architectural design of a built environment is the one that creates or has a significant influence on those nonmarket goods, as suggested by research regarding public policy outcomes as evidence of place value. Further identification and quantification are needed to better understand the mechanism of value transfers between architecture, the built environment, and public policy dimensions, including health, society, the economy, the environment, and the real estate market value.

The real estate valuation methods can be a tool for the quantification of the determinants of real estate market value. The broader view of the values generated from the built environment in the dimensions of public policy shows the areas of influence of broadly understood architecture on the market value of the property. The quantification of this influence should be the scope of a future study. The methods could be further improved according to the framework and, thereby, result in a better understanding of the impact of architecture on real estate market value. 


\section{REFERENCES}

Ahlfeldt, G., \& Mastro, A. (2012). Valuing Iconic Design: Frank Lloyd Wright Architecture in Oak Park, Illinois. Housing Studies, 27(8), 1079-1099. https://doi.org/10.1080/02673037.2012.728575

AI (1996). The appraisal of real estate. Appraisal Institute.

Anselin, L. (1988). Spatial econometrics: methods and models. Kluwer Academic Publishers.

Aranburu, I., Plaza, B., \& Esteban, M. (2016, Aug). Sustainable Cultural Tourism in Urban Destinations: Does Space Matter? Sustainability, 8(8), Article 699. https://doi.org/10.3390/su8080699

Asabere, P., Hachey, G., \& Grubaugh, S. (1989). Architecture, Historic Zoning, and the Value of Homes. The Journal of Real Estate Finance and Economics, 2, 181-195. https://doi.org/10.1007/BF00152347

Been, V., Ellen, I. G., Gedal, M., Glaeser, E., \& McCabe, B. J. (2016). Preserving history or restricting development? The heterogeneous effects of historic districts on local housing markets in New York City. Journal of Urban Economics, 92, 16-30. https://doi.org/10.1016/j.jue.2015.12.002

Bowler, D. E., Buyung-Ali, L., Knight, T. M., \& Pullin, A. S. (2010). Urban greening to cool towns and cities: A systematic review of the empirical evidence. Landscape and Urban Planning, 97(3), 147-155. https://doi.org/10.1016/j.landurbplan.2010.05.006

Buitelaar, E., \& Schilder, F. (2017). The Economics of Style: Measuring the Price Effect of Neo-Traditional Architecture in Housing. Real Estate Economics, 45(1), 7-27. https:/ / doi.org/10.1111/1540-6229.12137

Callicott, J. B., \& Shaner, D. E. (1989). In Defense of the Land Ethic: Essays in Environmental Philosophy. State University of New York Press.

Can, A. (1990). The Measurement of Neighborhood Dynamics in Urban House Prices. Economic Geography, 66(3), 254272. https://doi.org/10.2307/143400

Can, A. (1992). Specification and estimation of hedonic housing price models. Regional Science and Urban Economics, 22(3), 453-474. https://doi.org/10.1016/0166-0462(92)90039-4

Carmona, M. (2019). Place value: place quality and its impact on health, social, economic and environmental outcomes. Journal of Urban Design, 24(1), 1-48. https://doi.org/10.1080/13574809.2018.1472523

Carmona, M., De Magalhaes, C., Edwards, M., Awuor, B., \& Aminossehe, S. (2001). The Value of Urban Design. London: Thomas Telford.

Cellmer, R., \& Trojanek, R. (2019). Towards increasing residential market transparency: Mapping local housing prices and dynamics. ISPRS International Journal of Geo-Information, 9(1). https://doi.org/10.3390/ijgi9010002

Champ, P. A., Boyle, K., \& Brown, T. C. (2017). A Primer on Nonmarket Valuation. Dordrecht: Springer.

Chen, Y., Li, X., Zheng, Y., Guan, Y., \& Liu, X. (2011). Estimating the relationship between urban forms and energy consumption: A case study in the Pearl River Delta, 2005-2008. Landscape and Urban Planning, 102, 33-42. https://doi.org/10.1016/j.landurbplan.2011.03.007

Costanza, R., \& Folke, C. (1997). Valuing ecosystem services with efficiency, fairness and sustainability as goals. In G. Daily (Ed.), Nature's Services: Societal Dependence on Natural Ecosystems (pp. 49-70). Island Press.

Coulson, N. E., \& Lahr, M. L. (2005). Gracing the Land of Elvis and Beale Street: Historic Designation and Property Values in Memphis. Real Estate Economics, 33(3), 487-507. https://doi.org/10.1111/j.1540-6229.2005.00127.x

Dubin, R. A. (1988). Estimation of Regression Coefficients in the Presence of Spatially Autocorrelated Error Terms. The Review of Economics and Statistics, 70(3), 466-474. https://doi.org/10.2307/1926785

Ewing, R., \& Rong, F. (2008). The impact of urban form on U.S. residential energy use. Housing Policy Debate, 19(1), 130. https://doi.org/10.1080/10511482.2008.9521624

Fadaei, S., Iulo, L. D., \& Yoshida, J. (2015). Architecture: A missing piece in real-estate studies of sustainable houses. Defining the Future of Sustainability and Resilience in Design, Engineering and Construction, 118, 813-818. https://doi.org/10.1016/j.proeng.2015.08.518

Fuerst, F., McAllister, P., \& Murray, C. B. (2011). Designer Buildings: Estimating the Economic Value of 'Signature' Architecture. Environment and Planning A: Economy and Space, 43(1), 166-184. https://doi.org/10.1068/a43270

Gat, D. (1998). Urban Focal Points and Design Quality Influence Rents: The Case of the Tel Aviv Office Market. The Journal of Real Estate Research, 16(2), 229-247. 
Glaeser, E. L., Kincaid, M. S., \& Naik, N. (2018). Computer Vision and Real Estate: Do Looks Matter and Do Incentives Determine Looks. National Bureau of Economic Research Working Paper Series, No. 25174. https://doi.org/10.3386/w25174

Gong, Y., Boelhouwer, P., \& de Haan, J. (2016). Interurban house price gradient: Effect of urban hierarchy distance on house prices. Urban Studies, 53(15), 3317-3335. https://doi.org/10.1177/0042098015608090

Hayllar, B., Griffin, T., \& Edwards, D. (2008). City Spaces - Tourist Places: Urban Tourism Precincts. ButterworthHeinemann. https://doi.org/10.1016/B978-0-7506-8195-7.00019-6

Honold, J., Beyer, R., Lakes, T., \& van der Meer, E. (2012). Multiple environmental burdens and neighborhood-related health of city residents. Journal of Environmental Psychology, 32(4), 305-317. https://doi.org/10.1016/j.jenvp.2012.05.002

Hough, D. E., \& Kratz, C. G. (1983, 1983/07/01/). Can "good" architecture meet the market test? Journal of Urban Economics, 14(1), 40-54. https://doi.org/10.1016/0094-1190(83)90028-1

Hypostat (2019). Hypostat 2019: A Review of Europe's Mortgage and Housing Markets. (2019). European Mortgage Federation.

Jadevicius, A. (2016). Macro-determinants of the Lithuanian housing market: a test for Granger causality. Journal of Baltic Studies, 47(3), 385-398. https:/ / doi.org/10.1080/01629778.2016.1141105

Jamei, E., Rajagopalan, P., Seyedmahmoudian, M., \& Jamei, Y. (2016). Review on the impact of urban geometry and pedestrian level greening on outdoor thermal comfort. Renewable and Sustainable Energy Reviews, 54, 1002-1017. https://doi.org/10.1016/j.rser.2015.10.104

Ko, Y., \& Radke, J. D. (2014). The Effect of Urban Form and Residential Cooling Energy Use in Sacramento, California. Environment and Planning B: Planning and Design, 41 (4), 573-593. https://doi.org/10.1068/b12038p

Lazrak, F., Nijkamp, P., Rietveld, P., \& Rouwendal, J. (2014). The market value of cultural heritage in urban areas: an application of spatial hedonic pricing. Journal of Geographical Systems, 16(1), 89-114. https://doi.org/10.1007/s10109-013-0188-1

Le Sage, J. P. (1998). Spatial econometrics. Unpublished manuscript.

Le Sage, J. P., \& Pace, R. K. (2009). Introduction to Spatial Econometrics. CRC Press.

Lee, S., \& Lee, B. (2014). The influence of urban form on GHG emissions in the U.S. household sector. Energy Policy, 68, 534-549. https://doi.org/10.1016/j.enpol.2014.01.024

Macmillan, S. (2006). Added value of good design. Building Research \& Information, 34(3), 257-271. https://doi.org/10.1080/09613210600590074

Nakamura, K., \& Hayashi, Y. (2013). Strategies and instruments for low-carbon urban transport: An international review on trends and effects. Transport Policy, 29, 264-274. https://doi.org/10.1016/j.tranpol.2012.07.003

Nasdaq Baltic. (2019). Retrieved March 7, 2020, from https://www.nasdaqbaltic.com/

Nase, I., Berry, J., \& Adair, A. (2015). Urban design quality and real estate value: in search of a methodological framework. Journal of Urban Design, 20(5), 563-581. https://doi.org/10.1080/13574809.2015.1071657

Nase, I., Berry, J., \& Adair, A. (2016). Impact of quality-led design on real estate value: a spatiotemporal analysis of city centre apartments. Journal of Property Research, 33(4), 309-331. https://doi.org/10.1080/09599916.2016.1258588

Rashkin, S. (2010). Retooling the U.S. Housing Industry: How It Got Here, Why It's Broken, How To Fix It. Cengage Learning.

Ratti, C., Baker, N., \& Steemers, K. (2005). Energy consumption and urban texture. Energy and Buildings, 37(7), 762776. https://doi.org/10.1016/j.enbuild.2004.10.010

RICS (2019). RICS Valuation - Global Standards. Royal Institution of Chartered Surveyors.

Rudokas, K., Landauskas, M., Viliūnienè, O., \& Gražulevičiūtė-Vileniškè, I. (2019). Hedonic analysis of housing prices and development in Kaunas: heritage aspect. Environmental research, engineering and management, 75(2), 15-27. https://doi.org/10.5755/j01.erem.75.2.22823

Scerri, M., Edwards, D., \& Foley, C. (2019). Design, architecture and the value to tourism. Tourism Economics, 25(5), 695-710. https://doi.org/10.1177/1354816618802107

Stamou, M., Mimis, A., \& Rovolis, A. (2017). House price determinants in Athens: a spatial econometric approach. Journal of Property Research, 34(4), 269-284. https://doi.org/10.1080/09599916.2017.1400575 
Trojanek, R. (2016). The Impact of Green Areas on Dwelling Prices: the Case of Poznań City. Entrepreneurial Business and Economics Review, 4(2), 27-35. https://doi.org/10.15678/EBER.2016.040203

Trojanek, R., \& Huderek-Glapska, S. (2018). Measuring the noise cost of aviation - The association between the Limited Use Area around Warsaw Chopin Airport and property values. Journal of Air Transport Management, 67(July 2017), 103-114. https://doi.org/10.1016/j.jairtraman.2017.12.002

Trojanek, R., Tanas, J., \& Trojanek, M. (2019). The effect of perpetual usufruct on single- family house prices in Poznań. Journal of International Studies, 12, 212-221. https://doi.org/10.14254/2071-8330.2019/12-3/17

Vandell, K. D., \& Lane, J. S. (1989). The Economics of Architecture and Urban Design: Some Preliminary Findings. Real Estate Economics, 17(2), 235-260. https://doi.org/10.1111/1540-6229.00489

Wilhelmsson, M. (2002). Spatial Models in Real Estate Economics. Housing, Theory and Society, 19(2), 92-101. https://doi.org/10.1080/140360902760385646

Wilhelmsson, M. (2004). A method to derive housing sub-markets and reduce spatial dependency. Property Management, 22(4), 276-288. https://doi.org/10.1108/02637470410558143

Zhou, J., Lin, J., Cui, S., Qiu, Q., \& Zhao, Q. (2013). Exploring the relationship between urban transportation energy consumption and transition of settlement morphology: A case study on Xiamen Island, China. Habitat International, 37, 70-79. https://doi.org/https://doi.org/10.1016/j.habitatint.2011.12.008 